\title{
An Efficient Chemoenzymatic Synthesis of Coenzyme A and Its Disulfide
}

\author{
Louis M. M. Mouterde and Jon D. Stewart* \\ Department of Chemistry, 126 Sisler Hall, University of Florida, Gainesville, FL 32611 USA \\ Phone \& Fax 352.846.0743, E-mail jds2@ chem.ufl.edu \\ *Author to whom correspondence should be addressed
}


Table of Contents Graphic

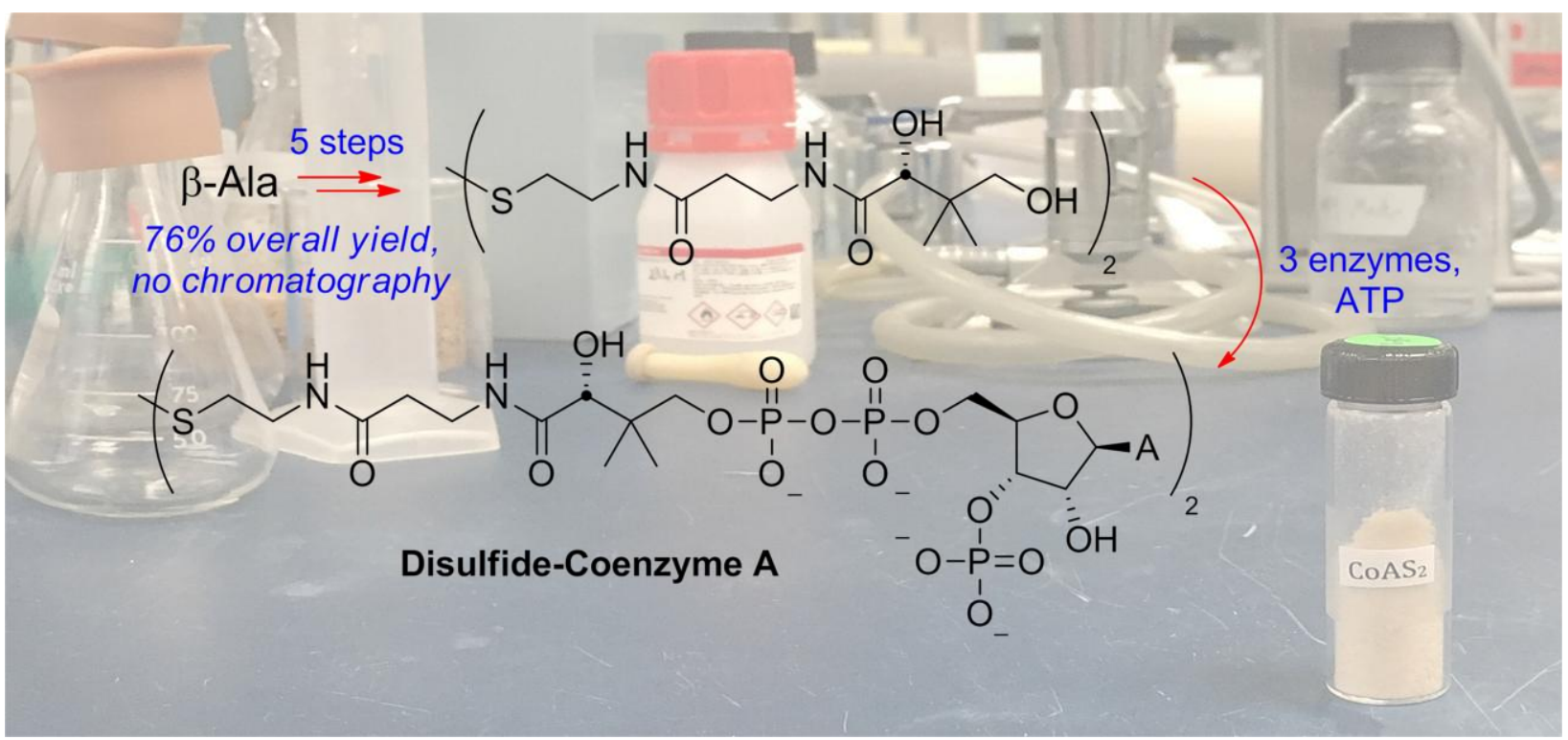




\begin{abstract}
We have developed a chemoenzymatic route to coenzyme A (CoASH) and its disulfide that is amenable to gram-scale synthesis using standard laboratory equipment. By synthesizing the symmetrical disulfide of pantetheine (pantethine), we avoided the need to mask the reactive sulfhydryl and also prevented sulfur oxidation by-products. No chromatography is required in our synthetic route to pantethine, which facilitates scale-up. Furthermore, we discovered that all three enzymes of the CoASH salvage pathway (pantetheine kinase, phosphopantetheine adenyltransferase and dephosphocoenzyme A kinase) accept the disulfide of the natural substrates and functionalize both ends of the molecules. This yields CoA disulfide as the product of the enzymatic cascade, a much more stable form of the cofactor. Free CoASH can be prepared by in situ $S-S$ reduction.
\end{abstract}

Keywords: Coenzyme A, chemo-enzymatic synthesis, disulfide, pantetheine, pantethine 


\section{Introduction}

Coenzyme A (CoASH) is an essential acyl carrier and co-substrate for many biochemical processes. In addition to recognizing the acyl moiety of CoA derivatives, cognate enzymes also commonly interact with the cofactor portion and show little tolerance for structural perturbations (1). One must therefore supply native CoA intermediates in stoichiometric quantities for such enzymes. This is particularly relevant for enzyme-mediated aldol reactions and Claisen condensations, which are commonly used to form $C$ - $C$ bonds in many metabolic pathways. Such reactions might also be highly useful in chemical synthesis; unfortunately, enthusiasm for this approach must be tempered by the high cost of commercial CoASH $(\$ 2600 / \mathrm{g}$ with $>85 \%$ purity). To remove this obstacle, we have developed a simple chemoenzymatic route to $\mathrm{CoASH}$ that can be carried out on gram scales and requires no chromatographic purification until the final target has been reached. Synthesis of the enzyme substrate requires only five steps and has a $76 \%$ overall yield from commercially available $\beta$-alanine.

Preparative quantities of CoASH have been isolated from microbial sources such as bakers' yeast (2) or Brevibacterium ammoniagenes IFO 12071 (3). Dried cells of wild-type or mutant B. ammoniagenes were subsequently used in chemo-enzymatic routes since they contained all five of the necessary CoASH biosynthetic enzymes (4). More recently, enzyme-assisted strategies have been developed by several groups for CoASH and its analogs (5) based on fundamental biochemical studies by

Drueckhammer (6), Strauss and Begley (7), and Jackowski (8). Our route to CoASH was inspired by the work of Strauss and Begley and employs the three-enzyme cascade of the CoASH salvage pathway (Scheme 1). All three steps are ATP-dependent and the proteins from Escherichia coli have been cloned and overexpressed $(6 \mathrm{~b}, 8 \mathrm{~d}, 9)$. Initial phosphorylation of $\mathbf{1}$ by pantetheine kinase (PanK) yields $\mathbf{2}$, whose adenylation by phosphopantetheine adenyltransferase (PPAT) provides dephospho-CoA 3. The final step installs the 2'-phosphate using dephospho-coenzyme A kinase (DCPK) to yield CoASH. In principle, all three enzymes could be present simultaneously; however, most PPAT enzymes (including 
the E. coli form) are subject to feedback inhibition by CoASH (8c). This makes successive enzymecatalyzed reactions more convenient for preparative purposes, an approach pioneered by Wright (5b). The three enzyme-catalyzed steps in CoASH production need little or no optimization; what discourages their large-scale use is the lack of an economical source for the substrate. One key observation is that the three enzymes tolerate significant structural alterations at the sulfhydryl moiety and this has allowed CoASH analogs to be synthesized by the same route (5). Based on this, we hypothesized that the three enzymes might therefore accept a disulfide dimer of pantetheine (known as pantethine) and simultaneously functionalize both ends, ultimately producing the disulfide of CoASH.
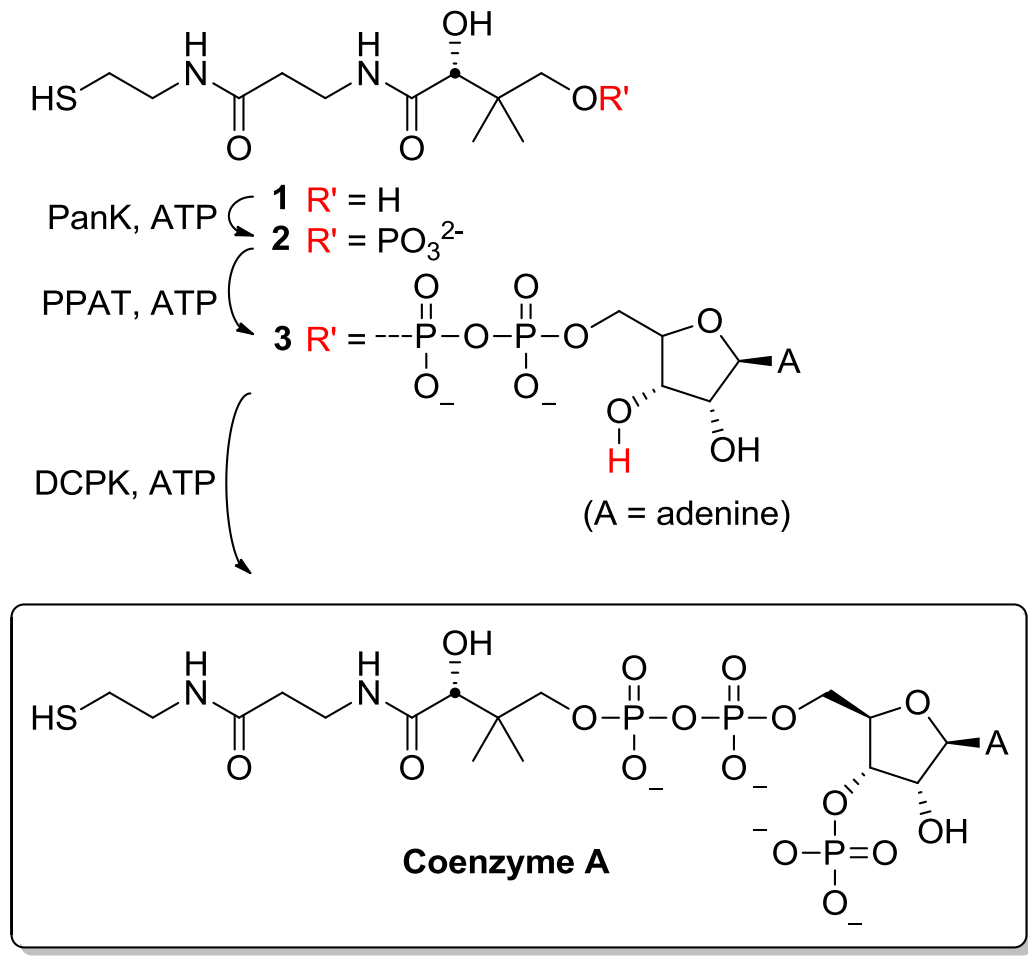

\section{Scheme 1}

We chose the disulfide derivative of $\mathbf{1}$ as the biocatalytic precursor for several reasons. First, a disulfide eliminates the two steps needed to install and later remove the sulfhydryl protecting group. In a sense, our "protecting group" is a second molecule of the target compound. This is an atom economical strategy that eliminates carrying extraneous mass through the sequence. A disulfide also 
diminishes the chances of forming sulfur oxidation by-products during the synthetic operations. The dimeric intermediates were organic-soluble, which allowed the desired products to be isolated by solvent extraction with no need for chromatographic purification. This is a significant advantage when scaling up the chemical synthesis steps. Finally, the commercial price of oxidized CoASH - the product of our synthetic route - is almost 10-fold greater than that of CoASH itself (10).

In principle, the biocatalytic precursors (pantetheine $\mathbf{1}$ or pantethine $\mathbf{8}$ ) could also be synthesized enzymatically or obtained commercially; however, we found it more convenient to prepare the building block by traditional organic methodologies (Scheme 2). While routes to $\mathbf{1 ,} \mathbf{8}$ and analogs are known (5a, 11), our goals were to optimize each reaction and eliminate chromatographic separations that would hinder scale-up. We also sought a simple method to isolate the disulfide of CoASH on a preparative scale that avoided HPLC. 


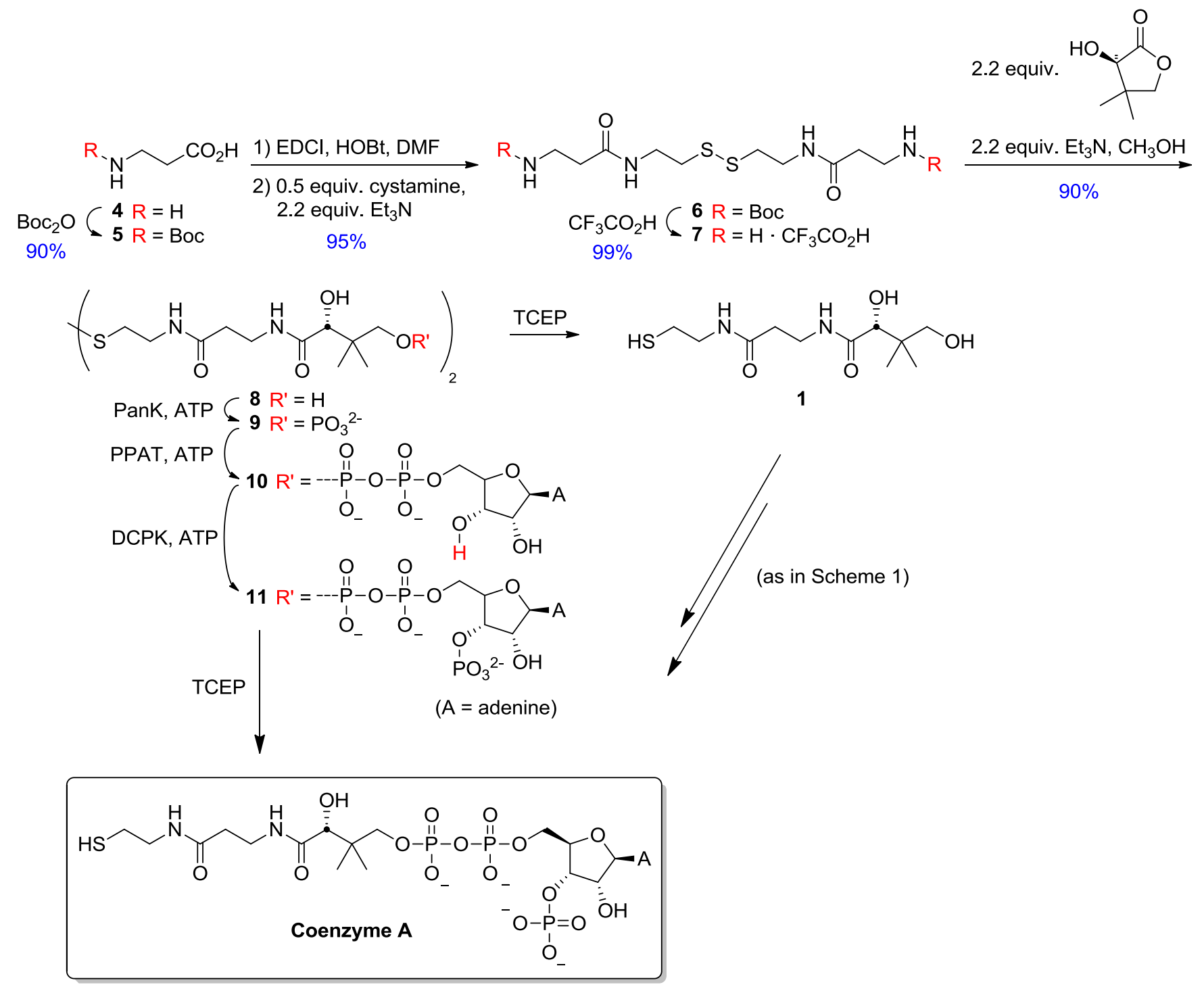

\section{Scheme 2}

\section{Results and Discussion}

To synthesize panthethine $8, \beta$-alanine 4 was reacted with a slight excess of $\mathrm{Boc}_{2} \mathrm{O}$ at $0^{\circ} \mathrm{C}$ to afford $N$-protected 5 in $90 \%$ yield (12),(13). The crude product, isolated by simple solvent extraction, was sufficiently pure to be used directly in the key coupling step with 0.50 equivalents of cysteamine disulfide (cystamine). Initial attempts using $\mathrm{PPh}_{3}, \mathrm{I}_{2}$ and imidazole in $\mathrm{CH}_{2} \mathrm{Cl}_{2}$ gave 6 in only $15-20 \%$ yield; in addition, the phosphine oxide by-product had nearly the same mobility on silica gel 
chromatography as $\mathbf{6}$. One solution was to synthesize a linear polystyrene with pendant phosphines (14), which was used in place of free $\mathrm{PPh}_{3}$. Unfortunately, because both $\mathbf{6}$ and the polymeric reagent were soluble in $\mathrm{CH}_{2} \mathrm{Cl}_{2}$, post-reaction separation remained an issue (15). We achieved smooth coupling of 5 and cystamine by employing EDCI and HOBt (16). Several aspects of this process were optimized to facilitate scale-up. In addition to the originally-reported solvent $\left(\mathrm{CH}_{2} \mathrm{Cl}_{2}\right)$, we also screened several other conditions. DMF at room temperature proved best along with dropwise addition of cystamine. Most importantly, we eliminated column chromatography by judicious extractions that removed both HOBt and the carbodiimide by-product and provided 6 in $95 \%$ yield with no need for further purification. Formation of a symmetrical dimer with no contamination by monoacylation product was confirmed by the observation of only 8 signals in the ${ }^{13} \mathrm{C}$ NMR spectrum of 6 .

The Boc group was removed quantitatively using TFA to yield ammonium salt 7 (17). This was coupled with D-pantolactone by heating an ethanolic solution at reflux in the presence of excess $\mathrm{Et}_{3} \mathrm{~N}$ as described by King et al. (11). Pantethine 8 was isolated after solvent extraction. The four nonenzymatic steps proceeded in $76 \%$ overall yield on gram scales and no column chromatography was required. We believe that this route is thus amenable to scale-up. Moreover, this process give an easy access to pantetheine $\mathbf{1}$ by TCEP reduction (or other reducing agent as 2-mercaptoethanol).

Base-catalyzed racemization of D-pantolactone, e.g., when heated in DMF, has been reported (18). Because our conversion of $\mathbf{7}$ to $\mathbf{8}$ involved heating an ethanolic solution of D-pantolactone in the presence of $\mathrm{Et}_{3} \mathrm{~N}$, we carried out a control reaction to determine whether racemization might have occurred prior to coupling. Optically pure D-(-)-pantolactone was heated at reflux in EtOH overnight in presence of 5 equivalents of $\mathrm{Et}_{3} \mathrm{~N}$, which mimicked the reaction conditions employed in the coupling step. Chiral-phase GC analysis of the reaction mixture revealed only a single peak for pantolactone within the detection limits of the instrument (19). Based on these results, and the ${ }^{13} \mathrm{C}$ NMR spectrum of 
$\mathbf{8}$, we believe that our reaction product is diastereomerically pure and that no significant racemization took place.

Before attempting the enzymatic cascade with the disulfide, we carried out pilot experiments with the known substrate $\mathbf{1}$. The disulfide bond of $\mathbf{8}$ was reduced quantitatively by a slight molar excess of tris(2-carboxyethyl)phosphine (TCEP) in the buffer used for the enzyme-catalyzed reactions ( $75 \mathrm{mM}$ Tris-Cl, $25 \mathrm{mM} \mathrm{KCl}, 250 \mathrm{mM} \mathrm{MgCl} 2, \mathrm{pH} 7.5$ ). The crude product was used directly as a substrate for the three successive enzyme-catalyzed reactions using PanK, PPAT and DPCK in the presence of excess ATP to ensure that all conversions proceeded to completion (Scheme 1). This sequence yielded a sample of CoASH whose HPLC and MS data were identical to those of commercially-supplied material. These reactions were performed on a small scale and quantitative conversion was observed at each step according to HPLC analysis (Figure 1). As expected, the intermediates and final product were somewhat unstable in the presence of oxygen, likely because of thiol oxidation.

To avoid side-reactions involving the free thiol of $\mathbf{1}$ and its derivatives, we employed disulfide $\mathbf{8}$ as an alternate substrate for the three CoASH salvage enzymes. The limited solubility of pyrophosphate in the presence of $\mathrm{Mg}^{2+}$ caused precipitation during reactions with PPAT at high substrate concentrations, which interfered with the enzymatic reaction. Filtration to remove the salt followed by adding additional PPAT solved this issue. Quantitative conversions were observed for each step (as monitored by HPLC; Figure 2).

To ensure that all the reactions had proceeded to completion at both ends of the symmetrical substrates, samples were reduced after each step with TCEP and analyzed by HPLC. In each case, only a single product was observed, corresponding to the intermediates in the sequence that commenced with 1.

We explored several strategies for purifying the disulfide of CoASH. Reversed-phase HPLC, while effective, had very low capacity that greatly limited its practical scalability. We initially used anion- 
exchange resins developed for protein purification, e.g., Mono-Q. These provided high product purities, but also suffered from limited capacities. Dowex anion exchange resin combined low material cost, high loading capacity and simple operation. After binding, increasing concentrations of $\mathrm{LiCl}$ were used to separate CoA disulfide 11 from by-product (20). A linear $\mathrm{LiCl}$ gradient yielded individual fractions containing AMP, ADP, ATP and 11, which allowed recovery of the adenosine by-products and regeneration into ATP if desired. For preparative purposes, however, we normally employed a simplified step gradient in which all the nucleotide by-products eluted as an initial group and the desired product 11 was eluted by $600 \mathrm{mM} \mathrm{LiCl}$. CoA disulfide was desalted by absorption on activated charcoal. Excess $\mathrm{LiCl}$ was removed by rinsing the activated charcoal with deionized water, then $\mathrm{CoA}$ disulfide was eluted with a $40 \%$ acetone solution containing $0.028 \%$ ammonia. The solution was concentrated under reduced pressure and the residual water was removed by lyophilization to yield the desired product (20).

The structure of synthetic CoA disulfide was verified by ${ }^{1} \mathrm{H},{ }^{13} \mathrm{C}$ and ${ }^{31} \mathrm{P}$ NMR along with HRMS. All data supported the assignment and no extraneous peaks were observed. As expected, the ${ }^{31} \mathrm{P}$ spectrum showed only three peaks (a singlet at $0.60 \mathrm{ppm}$ and doublets at -10.27 and $-10.81 \mathrm{ppm}$ ), corresponding to the three phosphate moieties of $\mathbf{1 1}$. No other significant phosphorus-containing species were observed at the limits of ${ }^{31} \mathrm{P}$ NMR detection, further confirming that the reactions by all three CoASH salvage enzymes proceeded to completion at both ends of the molecule. The ${ }^{31} \mathrm{P}$ NMR data showed that anion exchange chromatography had successfully removed all nucleotide mono-, di- or triphosphosphate by-products from the enzyme-catalyzed steps. The chemical purity of CoA disulfide purity was assessed by UV absorbance $\left(\varepsilon^{260}=14,320\right)$ and found to be $c a .82 \%$. For biochemical purposes, the cofactor can be used directly in this form (21). As HPLC and NMR analysis showed only CoA disulfide, we attributed the mass impurity to inorganic salts (most likely $\mathrm{LiCl}$ carried over from ion exchange purification). Consistent with this notion, the purity of CoA disulfide could be raised to $90 \%$ 
by a second adsorption / desorption treatment with activated charcoal (22). Similar values for purity were found by both UV absorbance and elemental analysis. The latter suggested that $\mathbf{1 1}$ had been isolated as a hexakis-ammonium salt with two waters of hydration.

We found that solid CoA disulfide could be stored at room temperature in the presence of oxygen for at least one month with no evidence of by-product formation. Coinjecting purified CoA disulfide with a commercial sample of CoASH gave two peaks using reversed-phase HPLC, as expected. When a slight molar excess of TCEP was added to the sample of CoA disulfide prior to HPLC analysis (23), only one peak was observed at the $t_{r}$ corresponding to free CoASH (11.47 min). This allows the cofactor to be stored as the stable disulfide, then reduced in situ as needed for biochemical applications.

Because of its high value, we also prepared the disulfide of 3'-dephospho-CoA using an analogous sequence of two enzyme-catalyzed steps (but leaving out the third, DCPK). While the synthetic effort itself was successful, the desired product co-eluted with ADP when the standard ion-exchange purification method was employed. Future efforts toward 3'-dephospho-CoA will require a revised purification method.

Using the optimized methods and standard laboratory equipment, we prepared $5 \mathrm{~g}$ batches of $\mathbf{8}$ in a single campaign. This was converted to CoA disulfide in lots of $1.89 \mathrm{~g}$ per reaction (each divided into two anion exchange runs) with a purity $\geq 90 \%$. This has allowed us to generate multi-gram amounts of the cofactor in approximately two weeks. The yield of purified CoA disulfide from precursor $\mathbf{8}$ was $95 \%$; the overall yield of the sequence starting from $\beta$-alanine was $72 \%$.

\section{Conclusion}

A simple chemo-enzymatic route to CoASH has been developed that emphasizes high yield and scalability. No chromatographic purification steps are required until the final target has been reached. Because the CoASH salvage pathway enzymes (PanK, PPAT and DPCK) can all accommodate disulfide 
dimer substrates, we could prepare an even higher-value CoASH derivative, eliminate thiol protection / deprotection steps and avoid the possibility of sulfur oxidation by-products. We hope that this chemoenzymatic methodology can enable further progress in using CoA-dependent enzymes in chemical synthesis by making the substrates more easily obtainable. While we currently have no plans to increase the reaction scales further, none of the procedures would appear to be problematic should future needs dictate further scale-up.

\section{Experimental Section}

General. Moisture- and $\mathrm{O}_{2}$-sensitive reactions were carried out in flame-dried glassware under Ar. Evaporations were conducted under reduced pressure at temperatures below $35^{\circ} \mathrm{C}$ unless otherwise noted. ${ }^{1} \mathrm{H}$ NMR spectra were recorded at $300 \mathrm{MHz}$ at $25^{\circ} \mathrm{C}$ in the indicated solvent and referenced to residual protons $\left(\mathrm{CDCl}_{3}, 7.26 \mathrm{ppm} ; \mathrm{CD}_{3} \mathrm{OD}, 4.87 \mathrm{ppm} ; \mathrm{D}_{2} \mathrm{O}, 4.75 \mathrm{ppm}\right) .{ }^{13} \mathrm{C}$ NMR spectra were recorded at $75 \mathrm{MHz}$ at $25^{\circ} \mathrm{C}$ in the indicated solvent and referenced to solvent $\left(\mathrm{CDCl}_{3}, 77.2 \mathrm{ppm}\right.$; $\left.\mathrm{CD}_{3} \mathrm{OD}, 49.2 \mathrm{ppm}\right) .{ }^{31} \mathrm{P}$ NMR spectra were recorded at $121 \mathrm{MHz}$ at $25^{\circ} \mathrm{C}$ in $\mathrm{D}_{2} \mathrm{O}$ and referenced to the solvent deuterium lock frequency.

HPLC methods. Enzymatic reactions were monitored by reversed-phase HPLC using a $150 \times 4.6$ mm Synergi ${ }^{\mathrm{TM}}$ Hydro-RP 80Å column using 50 mM NaP $\mathrm{pH} 5.0$ and $50 \mathrm{mM} \mathrm{NaP}$, pH 5.0 / $20 \%$ acetonitrile as Solvents A and B, respectively at a flow rate of $1 \mathrm{~mL} / \mathrm{min}$. Initial conditions (3\% B) were maintained for $2.5 \mathrm{~min}$, then a linear increase to $18 \%$ B over 5 min was immediately followed by a linear increase to $28 \%$ B over $3.5 \mathrm{~min}$, then a linear increase to $90 \%$ B over $10 \mathrm{~min}$. After a 5 min hold at $90 \% \mathrm{~B}$, a linear decrease to $3 \% \mathrm{~B}$ over 3 min was followed by a $5 \mathrm{~min}$ hold at the initial conditions (3\% B). The eluant was monitored by UV absorbance simultaneously at both 220 and $260 \mathrm{~nm}$ (to detect peptide bonds and adenyl moieties, respectively). These conditions allowed baseline separation of all

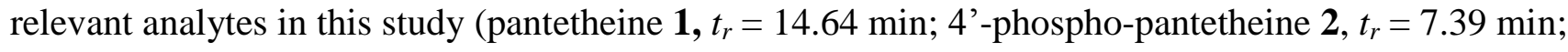


dephospho CoASH 3, $t_{r}=13.36 \mathrm{~min}$; CoASH $t_{r}=11.49 \mathrm{~min}$; pantethine 8, $t_{r}=20.86 \mathrm{~min}$; 4'-phosphopantethine 9, $t_{r}=14.67 \mathrm{~min}$; dephospho-CoASH disulfide 10, $t_{r}=16.27 \mathrm{~min}$; CoA disulfide 11, $t_{r}=$ $14.18 \mathrm{~min})$.

3-((tert-butoxycarbonyl)amino)propanoic acid 5. To a stirred solution of 3-amino-propanoic acid $(5.00 \mathrm{~g}, 55.7 \mathrm{mmol})$ in $10 \% \mathrm{NaOH}(50 \mathrm{~mL})$ at $0^{\circ} \mathrm{C}$ was slowly added 1.2 equiv. of Boc anhydride $(15$ $\mathrm{mL}, 66.7 \mathrm{mmol})$. The resulting mixture was allowed to warm to room temperature. The reaction was monitored by TLC $\left(10 \% \mathrm{MeOH} / \mathrm{CHCl}_{3}\right)$ and when complete $(3 \mathrm{hr})$, the mixture was diluted with EtOAc (50 mL), brought to $\mathrm{pH} 2$ with $1 \mathrm{M} \mathrm{HCl}$, and the layers separated. The organic layer was washed with water $(15 \mathrm{~mL})$ and brine $(15 \mathrm{~mL})$, then dried over $\mathrm{MgSO}_{4}$. The drying agent was rinsed with $20 \mathrm{~mL}$ of ice-cold hexanes and concentrated in vacuo. The resulting oil was dissolved in a minimum volume of $\mathrm{CH}_{2} \mathrm{Cl}_{2}$ and added slowly to a stirred solution of pentane $(100 \mathrm{~mL})$ cooled to $0^{\circ} \mathrm{C}$. The resulting white solid was collected by filtration $(9.99 \mathrm{~g}, 90 \%)$. m.p. $76-77^{\circ} \mathrm{C}$, lit. m.p. $75-77^{\circ} \mathrm{C}(24) .{ }^{1} \mathrm{H}$ and ${ }^{13} \mathrm{C}$ NMR data matched those reported by McCubbin et al. (25).

\section{di-tert-Butyl(((disulfanediylbis(ethane-2,1-diyl))bis(azanediyl))bis(3-oxopropane-3,1-}

diyl))dicarbamate 6. To a stirred solution of $5(4.00 \mathrm{~g}, 21.1 \mathrm{mmol})$ in DMF (40 mL) at rt was added HOBt (2.45 g, $21.1 \mathrm{mmol})$ followed by EDCI $(3.71 \mathrm{~mL}, 21.1 \mathrm{mmol})$. The reaction was stirred for 30 min, then a solution containing 0.5 equiv. of cystamine $(2.38 \mathrm{~g}, 10.6 \mathrm{mmol})$ and 2.2 equiv. of $\mathrm{Et}_{3} \mathrm{~N}(6.30$ $\mathrm{mL}, 46.4 \mathrm{mmol})$ in DMF (10 mL) was added dropwise. The mixture was stirred overnight, then diluted 5-fold with water and extracted with $\mathrm{Et}_{2} \mathrm{O}(3 \times 200 \mathrm{~mL})$. The combined organic layers were washed successively with $30 \mathrm{~mL} 1 \mathrm{M} \mathrm{HCl}, 10 \% \mathrm{NaHCO}_{3}$ and water, then dried over $\mathrm{MgSO}_{4}$. The solution was concentrated in vacuo and the desired product 6 was obtained as a white solid (4.95 g, 95\%). m.p. 102$103^{\circ} \mathrm{C}$. HRMS: $\mathrm{m} / \mathrm{z}[\mathrm{M}+\mathrm{H}]^{+}$calcd for $\mathrm{C}_{20} \mathrm{H}_{38} \mathrm{O}_{6} \mathrm{~N}_{4} \mathrm{~S}_{2}$ : 495.2306; found: 495.2326. ${ }^{1} \mathrm{H}$ NMR (300 $\left.\mathrm{MHz}_{\mathrm{CDCl}}\right): \delta 6.72(\mathrm{~s}, 2 \mathrm{H}), 5.28(\mathrm{~s}, 2 \mathrm{H}), 3.57(\mathrm{q}, J=6 \mathrm{~Hz}, 4 \mathrm{H}), 3.41(\mathrm{q}, J=6 \mathrm{~Hz}, 4 \mathrm{H}), 2.83(\mathrm{t}, J=6$ 
$\mathrm{Hz}, 4 \mathrm{H}), 2.45(\mathrm{t}, J=6 \mathrm{~Hz}, 4 \mathrm{H}), 1.44(\mathrm{~s}, 18 \mathrm{H}) \mathrm{ppm} .{ }^{13} \mathrm{C} \mathrm{NMR}\left(75 \mathrm{MHz}, \mathrm{CDCl}_{3}\right): \delta 171.9,155.9,78.9$,

38.2, 37.4, 36.6, 35.9, $28.1 \mathrm{ppm}$.

$N, N^{\prime}$-(Disulfanediylbis(ethane-2,1-diyl))bis(3-aminopropanamide) $\cdot\left(\mathrm{CF}_{3} \mathrm{CO}_{2} \mathrm{H}\right)_{2} 7$. Excess $\mathrm{CF}_{3} \mathrm{CO}_{2} \mathrm{H}(37.3 \mathrm{~mL}, 487.19 \mathrm{mmol})$ was added to a solution of $\mathbf{6}(4.82 \mathrm{~g}, 9.74 \mathrm{mmol})$ in $\mathrm{CH}_{2} \mathrm{Cl}_{2}(100$ $\mathrm{mL}$ ) at rt. The reaction mixture was allowed to stir for $6 \mathrm{hr}$, then the solvent was removed in vacuo to afford the crude product as the bis-trifluoroacetate salt $(5.08 \mathrm{~g}, 99 \%)$. HRMS: $\mathrm{m} / \mathrm{z}[\mathrm{M}+\mathrm{H}]^{+}$calcd for $\mathrm{C}_{10} \mathrm{H}_{22} \mathrm{O}_{2} \mathrm{~N}_{4} \mathrm{~S}_{2}$ : 295.4320; found: 295.1248. ${ }^{1} \mathrm{H}$ NMR (300 MHz, $\left.\mathrm{CD}_{3} \mathrm{OD}\right): \delta 8.31$ (s, 6H), 8.01 (s, 2H), $3.46(\mathrm{t}, J=6 \mathrm{~Hz}, 4 \mathrm{H}), 3.18(\mathrm{t}, J=6 \mathrm{~Hz}, 4 \mathrm{H}), 2.79(\mathrm{t}, J=6 \mathrm{~Hz}, 4 \mathrm{H}), 2.61(\mathrm{t}, J=6 \mathrm{~Hz}, 4 \mathrm{H}) \mathrm{ppm} .{ }^{13} \mathrm{C}$

NMR (75 MHz, CD 3 OD): $\delta 172.4,159.0\left(\mathrm{~d},{ }^{2} J=42 \mathrm{~Hz}\right), 116.0\left(\mathrm{q},{ }^{1} J=283 \mathrm{~Hz}\right), 39.6,38.3,37.2,33.0$ ppm.

(S)- $N$-((R)-17,19-Dihydroxy-18,18-dimethyl-3,12,16-trioxo-7,8-dithia-4,11,15-triazanonadecyl)2,4-dihydroxy-3,3-dimethylbutanamide 8. Three equivalents of D-(-)-pantolactone (3.73 g, 28.7 $\mathrm{mmol})$ and 2.5 equiv. of $\mathrm{Et}_{3} \mathrm{~N}(3.23 \mathrm{~mL}, 23.92 \mathrm{mmol})$ were added to a solution of $7(5 \mathrm{~g}, 9.57 \mathrm{mmol})$ in EtOH $(40 \mathrm{~mL})$. The solution was allowed to stir overnight at reflux. The solvent was evaporated under reduced pressure and excess D-(-)-pantolactone was removed by triturating the residue with diethyl ether $(2 \times 50 \mathrm{~mL})$. Solvent was removed in vacuo to afford $\mathbf{8}$ as an orange solid $(5.04 \mathrm{~g}, 90 \%) . \mathrm{mp}=63$ $65^{\circ} \mathrm{C}$. HRMS: $\mathrm{m} / \mathrm{z}[\mathrm{M}+\mathrm{Na}]^{+}$calcd for $\mathrm{C}_{10} \mathrm{H}_{23} \mathrm{O}_{2} \mathrm{~N}_{4} \mathrm{~S}_{2}: 577.1300$; found: 577.2309. ${ }^{1} \mathrm{H}$ NMR (300 $\left.\mathrm{MHz}, \mathrm{CD}_{3} \mathrm{OD}\right): \delta 3.95(\mathrm{~s}, 2 \mathrm{H}), 3.49(\mathrm{~m}, 12 \mathrm{H}), 2.82(\mathrm{t}, J=6 \mathrm{~Hz}, 4 \mathrm{H}), 2.48(\mathrm{t}, J=6 \mathrm{~Hz}, 4 \mathrm{H}), 0.89(2 \mathrm{~s}$, 12H). ${ }^{13} \mathrm{C}$ NMR $\left(75 \mathrm{MHz}, \mathrm{D}_{2} \mathrm{O}\right): 174.9,173.8,75.6,68.3,38.5,38.0,36.4,35.3,35.2,20.4,19.1 \mathrm{ppm}$. Overexpression and purification of PanK, PPAT, and DPCK. Individual plasmids that overexpressed E. coli PanK, PPAT, and DPCK (kindly provided by Prof. Steve Bruner, University of Florida; also available from Addgene) were used to transform E. coli BL21(DE3) cells with selection for kanamycin resistance $(50 \mu \mathrm{g} / \mathrm{mL})$ on LB plates. Single colonies of the appropriate strains were used to 
inoculate $50 \mathrm{~mL}$ portions of liquid LB medium containing $50 \mu \mathrm{g} / \mathrm{mL}$ kanamycin and cultures were grown overnight at $37^{\circ} \mathrm{C}$ and $250 \mathrm{rpm}$. Aliquots $(40 \mathrm{~mL})$ were diluted into $4 \mathrm{~L}$ of the same medium in a New Brunswick M9 fermenter. Cultures were grown at $37^{\circ} \mathrm{C}$ with stirring at $600 \mathrm{rpm}$ and air flow at $6 \mathrm{~L}$ / min until reaching an optical density of 0.6 at $600 \mathrm{~nm}$. Overexpression of PanK, PPAT, or DPCK was induced by adding sterile isopropyl $\beta$-D-thiogalactopyranoside (IPTG) to a final concentration of 0.4 $\mathrm{mM}$, along with a solution of $16 \mathrm{~g}$ of dextrose in $100 \mathrm{~mL}$ of water. The culture was incubated for an additional $4 \mathrm{~h}$ at $30^{\circ} \mathrm{C}$, then the cells were harvested by centrifugation $\left(6000 \times g\right.$ at $4^{\circ} \mathrm{C}$ for $\left.15 \mathrm{~min}\right)$. The cell paste was resuspended in $20 \mathrm{~mL}$ of cold lysis buffer (50 mM Tris- $\mathrm{HCl}, \mathrm{pH} 8.0)$ and disrupted by two passages through a French pressure cell at 18,000 psi. The lysate was clarified by centrifugation $\left(18,000 \times g\right.$ for $20 \mathrm{~min}$ at $\left.4^{\circ} \mathrm{C}\right)$ and applied to a $5 \mathrm{~mL} \mathrm{Ni-NTA}$ agarose column (GE Healthcare) previously equilibrated with $20 \mathrm{~mL}$ of binding buffer $(20 \mathrm{mM} \mathrm{NaP}, 500 \mathrm{mM} \mathrm{NaCl}, 20 \mathrm{mM}$ imidazole, $\mathrm{pH}$ 7.4). The column was washed with binding buffer until the $A^{280}$ value returned to its baseline value, then the desired protein was eluted by washing with $20 \mathrm{mM} \mathrm{NaP}, 500 \mathrm{mM} \mathrm{NaCl}, 500 \mathrm{mM}$ imidazole, $\mathrm{pH}$ 7.4. The protein solution was concentrated at $4^{\circ} \mathrm{C}$ by ultrafiltration and typical yields of purified enzymes from $4 \mathrm{~L}$ cultures were 130 - $150 \mathrm{mg}$. Purified proteins were stored in $50 \%$ glycerol in $1 \mathrm{~mL}$ aliquots at $-80^{\circ} \mathrm{C}$.

CoASH synthesis. The reaction mixture contained $20 \mathrm{mM} \mathrm{KCl}, 10 \mathrm{mM} \mathrm{MgCl} 2,5 \mathrm{mM}$ ATP (5 $\mu \mathrm{mol}), 50 \mathrm{mM}$ Tris- $\mathrm{Cl}, \mathrm{pH} 7.5$, and $2.5 \mathrm{mM}$ pantethine $\mathbf{8}(2.5 \mu \mathrm{mol})$ in a final volume of $1 \mathrm{~mL}$. Two equivalents of solid TCEP ( $3 \mu \mathrm{mol})$ were added to produce pantetheine 1 in situ (23). The initial phosphorylation reaction was initiated by adding $0.17 \mathrm{mg}$ of purified PanK and incubating at rt for $2 \mathrm{hr}$. After this time, $0.16 \mathrm{mg}$ of purified PPAT and an additional $5 \mu \mathrm{mol}$ of ATP was added and incubation was continued (overnight at rt). Finally, $0.16 \mathrm{mg}$ of purified DPCK along with an additional $5 \mu \mathrm{mol}$ of ATP were added and incubation was continued overnight at rt. Samples were analyzed by reversedphase HPLC to ensure that conversions had proceeded to completion before the next enzyme was added. 
The purified product was characterized by MALDI MS: calcd. for $\mathrm{C}_{21} \mathrm{H}_{36} \mathrm{~N}_{7} \mathrm{O}_{16} \mathrm{P}_{3} \mathrm{~S}[\mathrm{M}+\mathrm{H}]^{+} 768.1152$; found 768.1242 .

CoA disulfide synthesis. The reaction mixture contained $25 \mathrm{mM} \mathrm{KCl,} 250 \mathrm{mM} \mathrm{MgCl} 2,30 \mathrm{mM}$ ATP (3.0 mmol), $75 \mathrm{mM}$ Tris-Cl, $\mathrm{pH} 7.5$, and $13 \mathrm{mM}$ pantethine $8(1.3 \mathrm{mmol}, 0.720 \mathrm{~g})$ in a final volume of $100 \mathrm{~mL}$. The reaction was initiated by adding $3 \mathrm{mg}$ of purified PanK and incubating at rt for $2 \mathrm{hr}$. After this time, $3 \mathrm{mg}$ of purified PPAT along with an additional $3.0 \mathrm{mmol}$ of ATP was added and incubation was continued (overnight at $\mathrm{rt}$ ). The $\mathrm{Mg} \cdot \mathrm{PP}_{\mathrm{i}}$ complex that precipitated during the reaction was removed by filtration. Finally, $3 \mathrm{mg}$ of purified DPCK and $3.0 \mathrm{mmol}$ of ATP were added and incubation was continued (overnight at rt). Samples were analyzed by reversed-phase HPLC to ensure that conversions had proceeded to completion before the next enzyme was added.

CoA disulfide was purified by injecting half of the crude reaction mixture $(50 \mathrm{~mL}$, containing $\mathrm{ca}$. 14 $\mathrm{mM}$ CoA disulfide) onto a $650 \times 25 \mathrm{~mm}$ Dowex $1 \times 2$ anion exchange column that had been equilibrated with solvent $\mathrm{A}(10 \mathrm{mM} \mathrm{HCl}, 300 \mathrm{mM} \mathrm{LiCl})$. The column was washed with solvent $\mathrm{A}$ for 180 min (to elute ATP, ADP and AMP), then the buffer was changed 100\% solvent B (10 mM HCl, 600 $\mathrm{mM} \mathrm{LiCl}$ ) for $120 \mathrm{~min}$ to elute CoA disulfide. The flow rate was $10 \mathrm{~mL} / \mathrm{min}$ throughout. Fractions containing CoA disulfide were then evaporated under vacuum. The material from both runs was combined. The resulting solid (33 g) was dissolved in a minimum volume of water (200 $\mathrm{mL})$ and brought to $\mathrm{pH} \approx 3$, then activated charcoal $(20 \mathrm{~g})$ was added. The resulting suspension was stirred for 30 minutes at $\mathrm{rt}$ and then the solid was collected by vacuum filtration. The filter cake was washed with $1 \mathrm{~L}$ of deionized water (adjusted to $\mathrm{pH} \approx 3$ ) to remove unwanted inorganic salts, then CoA disulfide 11 was eluted with a $40 \%(\mathrm{v} / \mathrm{v})$ aqueous acetone solution containing $0.028 \%$ ammonia. The combined solutions containing 11 were concentrated in vacuo to remove acetone, then water was removed by lyophilization to give the desired product $\mathbf{1 1}$ as a pale yellow solid (1.97 g). The adsorption onto activated charcoal was repeated a second time to provide analytically-pure 11 (1.89 g, 95\%). Purity was assessed by 
dissolving $5.0 \mathrm{mg}$ of purified $11 \mathrm{in} 100 \mathrm{~mL}$ of $1 \mathrm{M}$ Tris-Cl, $\mathrm{pH} 7.5$; this solution yielded $A^{260}=0.8013$.

Based on the extinction coefficient $\left(\varepsilon^{260}=14,320\right)$, the solution contained $4.5 \mathrm{mg}$ of 11 in $100 \mathrm{~mL}$.

Elemental analysis calcd. for $\mathrm{C}_{42} \mathrm{H}_{70} \mathrm{~N}_{14} \mathrm{O}_{32} \mathrm{P}_{6} \mathrm{~S}_{2} \cdot 6 \mathrm{NH}_{4} \cdot 2 \mathrm{H}_{2} \mathrm{O}: \% \mathrm{C} 30.15, \% \mathrm{H}$ 5.66, \%N 16.74; found $\% \mathrm{C} 27.42, \% \mathrm{H}$ 5.40, \%N 15.31. MALDI MS calcd. for $\mathrm{C}_{42} \mathrm{H}_{70} \mathrm{~N}_{14} \mathrm{O}_{32} \mathrm{P}_{6} \mathrm{~S}_{2}[\mathrm{M}+\mathrm{H}]^{+} 1533.2159$; found 1533.2234. ${ }^{1} \mathrm{H}$ NMR (300 MHz, $\left.\mathrm{D}_{2} \mathrm{O}\right): \delta 8.47(\mathrm{~s}, 2 \mathrm{H}), 8.14(\mathrm{~s}, 2 \mathrm{H}), 6.11(\mathrm{~d}, J=6 \mathrm{~Hz}, 2 \mathrm{H}), 4.67(\mathrm{~s}, 4 \mathrm{H})$, $4.55(\mathrm{~s}, 2 \mathrm{H}), 4.21(\mathrm{t}, J=3 \mathrm{~Hz}, 4 \mathrm{H}), 3.96(\mathrm{~s}, 2 \mathrm{H}), 3.78(\mathrm{~m}, 2 \mathrm{H}), 3.53(\mathrm{~m}, 2 \mathrm{H}), 3.38(\mathrm{~m}, 7 \mathrm{H}), 2.69(\mathrm{q}, J=6$

$\mathrm{Hz}, 4 \mathrm{H}), 2.41(\mathrm{t}, J=6 \mathrm{~Hz}, 4 \mathrm{H}), 1.34,1.24,0.84,0.71(4 \mathrm{~s}, 12 \mathrm{H}) .{ }^{31} \mathrm{P}\left(121 \mathrm{MHz}, \mathrm{D}_{2} \mathrm{O}\right): 0.60(\mathrm{~s}),-10.27(\mathrm{~d}$, $J=22 \mathrm{~Hz}),-10.81(\mathrm{~d}, J=22 \mathrm{~Hz}) .{ }^{13} \mathrm{C} \mathrm{NMR}\left(75 \mathrm{MHz}, \mathrm{D}_{2} \mathrm{O}\right): 174.6,173.7,155.0,152.4,148.9,139.6$, $118.2,86.5,83.5,74.1,73.9,71.8,65.5,58.0,38.3,36.5,35.3,35.2,20.8,18.2 \mathrm{ppm}$.

\section{Acknowledgements}

This work was partially supported by the National Science Foundation (CHE-1111791).

\section{Supporting Information}

NMR, HRMS and HPLC data for all intermediates and CoA disulfide (17 pages). 


\section{References and Notes}

(1) Polyketide synthases and non-ribosomal peptide synthases are exceptions to this rule and often accept acylated $N$-acetylcysteamines. Such synthases first catalyze transacylation to a covalentlylinked thioester intermediate, which is the actual substrate for subsequent conversions.

(2) (a) Beinert, H.; Von Korff, R. W.; Green, D. E.; Buyske, D. A.; Handschumacher, R. E.; Higgins, H.; Strong, F. M. J. Biol. Chem. 1953, 200, 385-400; (b) Reece, M. C.; Donald, M. B.; Crook, E. M. J. Biochem. Microbiol. Technol. Eng. 1959, 1, 217-228.

(3) (a) Shimizu, S.; Tani, Y.; Ogata, K. Meth. in Enzymol. 1979, 62, 236-245; (b) Shiozaki, S.; Shimizu, S.; Yamada, H. Agric. Biol. Chem. 1984, 48, 2293-2300.

(4) (a) Shimizu, S.; Esumi, A.; Komaki, R.; Yamada, H. Appl. Environ. Microbiol. 1984, 48, 1118 1122; (b) Shimizu, S.; Komaki, R.; Tani, Y.; Yamada, H. FEBS Lett. 1983, 151, 303-306.

(5) (a) Mandel, A. L.; La Clair, J. J.; Burkart, M. D. Org. Lett. 2004, 6, 4801-4803; (b) Nazi, I.; Koteva, K. P.; Wright, G. D. Anal. Biochem. 2004, 324, 100-105; (c) Rootman, I.; de Villiers, M.; Brand, L. A.; Strauss, E. ChemCatChem 2010, 2, 1239-1251.

(6) (a) Martin, D. P.; Drueckhammer, D. G. Biochem. Biophys. Res. Commun. 1993, 192, 1155-1161;

(b) Mishra, P. K.; Park, P. K.; Drueckhammer, D. G. J. Bacteriol. 2001, 183, 2774-2778.

(7) (a) Strauss, E.; Begley, T. P. J. Biol. Chem. 2002, 277, 48205-48209; (b) Strauss, E.; Kinsland, C.; Ge, Y.; McLafferty, F. W.; Begley, T. P. J. Biol. Chem. 2001, 276, 13513-13516; (c) Brand, L. A.; Strauss, E. J. Biol. Chem. 2005, 280, 20185-20188.

(8) (a) Leonardi, R.; Chohnan, S.; Zhang, Y.-M.; Virga, K. G.; Lee, R. E.; Rock, C. O.; Jackowski, S. J. Biol. Chem. 2005, 280, 3314-3322; (b) Leonardi, R.; Zhang, Y.-M.; Rock, C. O.; Jackowski, S. Prog. Lipid Res. 2005, 44, 125-153; (c) Rock, C. O.; Park, H.-W.; Jackowski, S. J. Bacteriol. 2003, 185, 3410-3415; (d) Song, W.-J.; Jackowski, S. J. Bacteriol. 1992, 174, 6411-6417; (e) 
Virga, K. G.; Zhang, Y.-M.; Leonardi, R.; Ivey, R. A.; Hevener, K.; Park, H.-W.; Jackowski, S.;

Rock, C. O.; Lee, R. E. Bioorg. Med. Chem. 2006, 14, 1007-1020.

(9) Geerlof, A.; Lewendon, A.; Shaw, W. V. J. Biol. Chem. 1999, 274, 27105-27111.

(10) The current price is approximately $\$ 200$ for 10 milligrams with $>85 \%$ purity.

(11) King, T. E.; Stewart, C. J.; Cheldelin, V. H. J. Am. Chem. Soc. 1953, 75, 1290-1292.

(12) Bock, M. G.; Gaul, C.; Gummadi, V. R.; Moebitz, H.; Sengupta, S. WO2012035078, Novartis A.G, 2012.

(13) Initial studies in which the Fmoc-protected $\beta$-alanine acid chloride was reacted with cystamine gave poor results, prompting us to substitute Boc protection.

(14) Kwok, M.; Choi, W.; He, H. S.; Toy, P. H. J. Org. Chem. 2003, 68, 9831-9834.

(15) Adding cross-links to the polymeric reagent likely would have solved this issue; however, the need to regenerate reduced phosphine from the polymeric phosphine oxide by-product discouraged our further efforts in this area.

(16) Maehara, T.; Kanno, R.; Yokoshima, S.; Fukuyama, T. Org. Lett. 2012, 14, 1946-1948.

(17) Guaragna, A.; Amoresano, A.; Pinto, V.; Monti, G.; Mastrobuoni, G.; Marino, G.; Palumbo, G. Bioconjugate Chem. 2008, 19, 1095-1104.

(18) Dueno, E. E.; Chu, F. X.; Kim, S. I.; Jung, K. W. Tetrahedron Lett. 1999, 40, 1843-1846.

(19) FID detection using a $0.25 \mathrm{~mm} \times 25 \mathrm{~m}$, Chirasil-DEX CB column. Racemic pantolactone analyzed under the same conditions gave baseline separation of the two enantiomers.

(20) Shimizu, S.; Miyata, K.; Tani, Y.; Ogata, K. Agric. Biol. Chem. 1973, 37, 615-619.

(21) In one example, we have prepared succinyl-CoA from CoA disulfide. In brief, an excess of TCEP was added to $100 \mu \mathrm{L}$ of a $10 \mathrm{mM}$ solution of $\mathbf{1 1}$ dissolved in water. After incubating at $\mathrm{rt}$ for 45 min, HPLC indicated complete disulfide reduction. The mixture was diluted with $800 \mu \mathrm{L}$ of sterile water and cooled to $0^{\circ} \mathrm{C}$, then an excess of finely-ground succinic anhydride was added and the 
mixture was kept on ice with periodic mixing for $30 \mathrm{~min}$. The reaction was quenched by adding $100 \mu \mathrm{L}$ of $1 \mathrm{M} \mathrm{NaHCO}_{3}$. HPLC indicated compete conversion of CoASH to succinyl-CoA

(22) Both UV absorbance and elemental analysis results were consistent with this purity assessment.

(23) Burns, J. A.; Butler, J. C.; Moran, J.; Whitesides, G. M. J. Org. Chem. 1990, 56, 2648-2650.

(24) Yasui, A.; Douglas, A. J.; Walker, B.; Magee, D. F.; Murphy, R. F. Int. J. Peptide Protein Res. 1990, 35, 301-305.

(25) McCubbin, J. A.; Maddess, M. L.; Lautens, M. Org. Lett. 2006, 8, 2993-2996. 
Figure Legends

Figure 1. HPLC characterization of pantatheine conversions. A. Pantetheine 1. B.

Phosphopantetheine 2. C. Dephospho-coenzyme A 3. D. Coenzyme A.

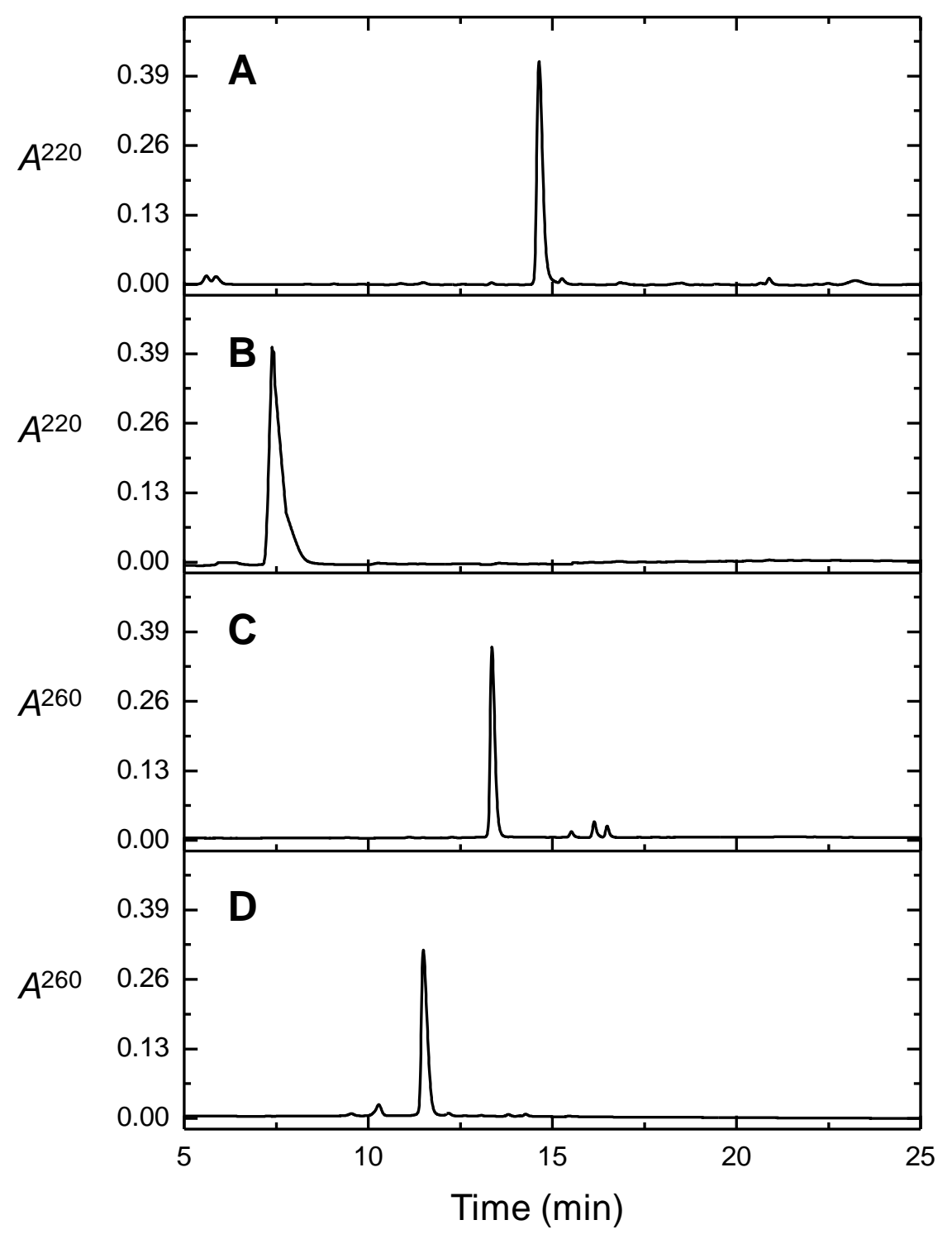


Figure 2. HPLC characterization of pantathine conversions. A. Pantethine 8. B.

Phosphopantethine 9. C. Dephospho-coenzyme A disulfide 10. D. Disulfide-coenzyme A 11.

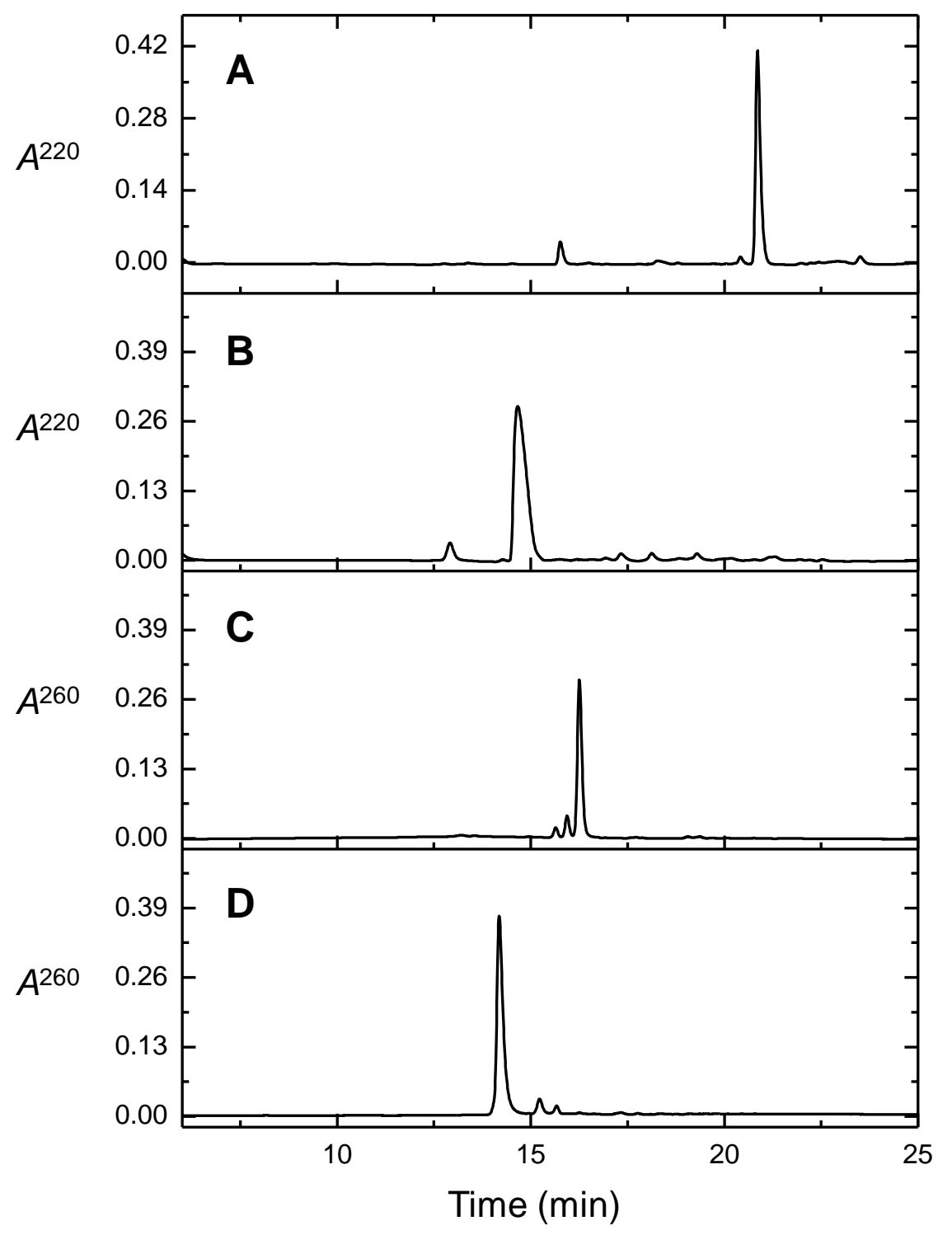


